\title{
Sobre a mudança do Instituto de Estudos Brasileiros para o Edifício Brasiliana
}

O Instituto de Estudos Brasileiros da Universidade de São Paulo ocupará, a partir de 2014, suas novas instalações no Edifício Brasiliana que já abriga, desde março de 2013, a Biblioteca Brasiliana Guita e José Mindlin, órgão da Pró-reitoria de Cultura e Extensão Universitária.

Fundado na década de 1960 por um grupo de professores e intelectuais ligados a esta Universidade, sob a liderança de Sérgio Buarque de Holanda, intelectual e professor de grande destaque no meio cultural e acadêmico brasileiro, o IEB desde seu início pretendeu ser um centro multidisciplinar e multitemático que congregasse estudos especializados sobre o Brasil das diversas áreas das Ciências Humanas.

Seu acervo inicia-se em 1962 com a aquisição da Brasiliana do historiador Yan de Almeida Prado, seguido por vários outros fundos pessoais de intelectuais brasileiros, entre eles Mário de Andrade, Guimarães Rosa, Graciliano Ramos, Pierre Monbeig, Marlise Meyer, Milton Santos e Anita Malfatti, compondo hoje um expressivo e rico conjunto de fontes primárias. Compreendendo documentos de diversas naturezas, os acervos desses estudiosos estão distribuídos entre o Arquivo, a Biblioteca e a Coleção de Artes Visuais da instituição, recebendo os cuidados necessários para a sua restauração, conservação e disponibilização pública, para o que o Instituto mantém também o Laboratório de Conservação e Restauro.

As atividades de ensino e pesquisa que nele se desenvolvem se fazem associadas à preservação dos acervos culturais sob sua guarda e essa articulação, constitutiva do Instituto, é responsável pelo seu permanente e crescente reconhecimento acadêmico.

De acordo com a especificação técnica, os diversos conjuntos documentais, mantidos integralmente, são trabalhados pelo Arquivo, Biblioteca e Coleção de Artes Visuais, a fim de garantir a preservação, organização e disponibilização pública.

O Arquivo surgiu em 1968, integrado à Biblioteca. Seu crescimento, com a chegada de sucessivos arquivos pessoais, motivou sua criação como setor independente, a partir de 1974, com o objetivo de receber, organizar, preservar e divulgar o acervo documental, visando oferecer fontes primárias para pesquisa.

A Biblioteca é considerada hoje uma das mais ricas em assuntos brasileiros, aproximando-se dos 180 mil volumes entre livros, periódicos, teses, separatas e partituras. Originou-se da famosa Brasiliana do 
historiador paulista Yan de Almeida Prado, comprada pela USP em 1962. O Instituto desde então, por compra ou doação, vem recebendo novas coleções, mantidas em sua unidade com os nomes de seus antigos proprietários, além da Coleção Geral, composta por doações, permutas e compras.

A Coleção de Artes Visuais iniciou-se com a compra, em 1968, da coleção formada por Mário de Andrade - artes plásticas, religião e magia, música e dança, cotidiano - e objetos relacionados à Revolução de 1932. O conjunto permaneceu como único acervo integrante da Coleção até 1981, data a partir da qual novas incorporações foram feitas.

A completa e perfeita integração entre esses três setores constituintes do IEB é responsável pela qualidade única das pesquisas que nele se desenvolvem dado que tal integração permite a consulta complementar entre documentos, livros e objetos constitutivos dos acervos dos vários intelectuais brasileiros revelando suas dinâmicas de trabalho e estrutura de pensamento.

Também estão diretamente envolvidos na preservação, organização e extroversão dos acervos o Laboratório de Conservação e Restauro e o Setor de Digitalização. O primeiro, criado em 2003, é especializado em papel, uma vez que grande parte do acervo do Instituto se compõe de obras neste tipo de suporte. Uma de suas principais atividades é a de avaliar permanentemente as condições dos documentos, livros e obras de arte, realizando sua conservação preventiva e, quando necessário, intervenções técnicas de restauro.

Já a estruturação do Setor de Digitalização do IEB iniciou-se em 2004 e ao longo dos últimos anos o setor ampliou e atualizou seus equipamentos, qualificou seus funcionários, estabeleceu critérios e diretrizes para a constituição e disponibilização de acervos digitais, desenvolveu bancos de dados e mecanismos de consulta on-line. Produz, em media, 100 mil imagens digitais/ano atendendo, além dos projetos desenvolvidos no próprio IEB, várias unidades da USP e pesquisadores de instituições nacionais e internacionais, cumprindo a importante tarefa de estabelecer interfaces internas e externas à Universidade.

Com o desenvolvimento de suas pesquisas e o crescimento de sua infra-estrutura, o Instituto passou a oferecer disciplinas de graduação abertas a alunos de todas as unidades da USP, cursos de extensão universitária para o público interessado e, mais recentemente, o programa multidisciplinar de pós-graduação stricto sensu em Culturas e Identidades Brasileiras.

Este universo crescente de atividades passou a demandar instalações não apenas maiores, mas especialmente projetadas para abrigar um instituto do porte e importância que o IEB adquiriu ao longo de seus 
50 anos de existência. Graças à visão e à atuação do Prof. Dr. István Jancsó, seu diretor entre 2000 e 2006, tais demandas se tornaram realidade. As novas instalações do Instituto aguardam alunos, pesquisadores e o público a partir do início de 2014.

Maria Angela Faggin Pereira Leite, Diretora do Instituto de Estudos Brasileiros 
